\title{
PENGARUH PELANGGARAN HAK PATEN APPLE TERHADAP PENGGUNA SMARTPHONE SAMSUNG DI INDONESIA
}

\author{
Wahyudi \\ 155100078, 785567907 \\ Fakultas Komputer \\ wahyudi.student@umitra.ac.id
}

\begin{abstract}
Penelitian ini membahas beberapa kasus pertikaian pelanggaran hak paten dari dua vendor smartphone ternama yaitu Apple dan Samsung. Beberapa Negara Asia, Eropa dan Amerika sudah mulai membatasi distribusi produk yang melanggar hak paten namun pembatasan be lum terjadi di Indonesia. Oleh sebab itu penelitian utama dari makalah ini adalah mengenai pengaruh pelanggaran hak paten Apple terhadap pengguna Samsung di Indonesia dengan memanfaatkan metode survey. Data responden yang diperoleh melalui proses pengujian reliabilitas, validitas, dan korelasi menggunakan software SPSS. Perhitungan yang dilakukan berdasarkan lima faktor yang diuji mempunyai dampak besar dalam penelitian ini.
\end{abstract}

Kata kunci: Hak Paten, Smartphone, Apple, Samsung. 


\section{A. INTRODUCTION}

Berdasarkan UU No. 14 Tahun 2001 Pasal 1 yang dimaksud Paten adalah hak eksklusif yang diberikan oleh Negara kepada Inventor atas hasil Invensinya di bidang teknologi, yang untuk selama waktu tertentu melaksanakan sendiri Invensinya tersebut atau memberikan persetujuannya kepada pihak lain untuk melaksanakannya.

Paten diberikan untuk jangka waktu selama 20 (duapuluh) tahun terhitung sejak Tanggal Penerimaan dan jangka waktu itu tidak dapat diperpanjang.

Smartphone

Dalam buku biografi resmi Steve Jobs karangan Walter Isaacsonyang terbit sesudah Jobs wafat itu itu, sang pendiri Apple berkata pada Isaacson bahwa pada zaman dulu dia mencoba berbagai variasi diet. Pernah dia hanya makan buah dan sayuran saja.

Apple menjadi salah satu kesukaan Jobs kala

diet. Dia spontan memutuskan memakai nama

Apple sepulang dari sebuah perkebunan

Apple. Alasannya, Jobs memilih Apple karena

nama ini dinilainya fun, bersemangat dan tidak mengintimidasi.

Kelebihan:
-Jumlah aplikasi dan games terbanyak dibanding OS smartphone lain.

-Punya kontrol ketat terhadap kualitas aplikasi yang ada di apps store.

-Performa \& kualitas menjalankan aplikasi/games lebih bagus dibanding smartphone dengan OS lainnya.

-Device-device lama bisa mendapat update OS walau secara hardware jauh tertinggal.

-Pelopor could computing (media penyimpanan data secara online).

-Garansi device internasional.

-Harga jual kembali lebih stabil.

\section{B. CONTENT}

yang terjadi antara Apple dan Samsung. Berikut ini beberapa hasil pertarungan pada pengadilan di beberapa Negara: Pengadilan Korea Selatan Di Seoul, Samsung mengajukan gugatan pada bulan Juni 2011 di Pengadilan Distrik Pusat mengutip lima pelanggaran paten. Pada akhir Agustus 2012 sebuah panel tiga hakim di Pengadilan Distrik Pusat Seoul memutuskan bahwa Apple melanggar dua paten teknologi Samsung, sementara Samsung melanggar salah satu paten Apple. Pengadilan memberikan ganti rugi kecil untuk kedua perusahaan dan memerintahkan penghentian 
penjualan dari produk yang melanggar di Korea Selatan, meskipun produk yang dilarang bukanlah model terbaru dari Samsung ataupun Apple. Pengadilan Distrik Pusat Seoul memutuskan bahwa Samsung melanggar salah satu paten utilitas Apple, apa yang disebut efek "bounce-back (bangkit kembali)" di IOS, dan bahwa Apple telah melanggar dua paten wireless Samsung. Klaim Apple bahwa Samsung menyalin desain iPhone dan iPad ditolak. Pengadilan juga memutuskan bahwa "tidak ada kemungkinan" bahwa konsumen akan bingung smartphone Samsung dan Apple, dan bahwa ikon smartphone Samsung tidak melanggar hak paten Apple. Pengadilan Jepang Keluhan Samsung di Pengadilan Distrik Tokyo Jepang menyebutkan dua pelanggaran. Apple telah mengajukan gugatan paten lainnya di Jepang melawan Samsung, terutama satu fitur "Bounce-Back". Samsung juga telah menuntut Apple, mengklaim iPhone dan iPad melanggar paten Samsung.Pada Jumat, 31 Agustus 2012, Pengadilan Distrik Tokyo memutuskan bahwa smartphone Samsung Galaxy dan tablet tidak melanggar paten Apple pada teknologi yang mensinkronisasikan musik dan video antara device dan server. Tiga hakim di Jepang juga memberikan ganti rugi yang akan dikembalikan kepada Samsung. Hakim Tamotsu Shoji mengatakan: "Produk terdakwa tidak tampak seperti mereka menggunakan teknologi yang sama seperti produk-produk penggugat sehingga kita mengecilkan pengaduan yang dibuat oleh Apple." Juru bicara yang tidak disebutkan namanya untuk Samsung mengatakan: "Kami akan terus menawarkan produk-produk yang sangat inovatif untuk konsumen, dan melanjutkan kontribusi kami terhadap pengembangan ini ustri mobile."Ronald A. Cass, konsultan hukum dan mantan wakil ketua Komisi Perdagangan Internasional, berkomentar: "Saya tidak akan berharap ada banyak pertimbangan seperti ini." Quote berdasarkan putusan dari pengadilan Amerika bukan pengadilan Jepang yang mengacu pada bagaimana sengketa paten didengar oleh juri. Pengadilan Jerman Pada bulan Agustus 2011, pengadilan

Landgericht di Düsseldorf, Jerman mengabulkan permintaan Apple untuk perintah pengadilan awal Uni Eropa-pembatasan Samsung menjual perangkat Galaxy Tab 10.1 dengan alasan produk Samsung melanggar dua hak paten interface Apple. Setelah bukti tuduhan sabotase Samsung terdengar, pengadilan mencabut perintah Uni Eropadan memberikan Apple 
perintah yang hanya berlaku untuk pasar Jerman. Samsung juga menarik Galaxy Tab 7.7 dari Berlin elektronik IFA karena keputusan itu mencegah pemasaran perangkat, sebelum pengadilan ditetapkan untuk membuat keputusan pada bulan September 2011. Menurut perkiraan Strategy Analytics, dampak pada Samsung, di Jerman, bisa menghabiskan biaya hingga setengah juta unit penjualan. Pada periode yang sama dan dalam kasus serupa strategi hukum yang terkait, Apple mengajukan gugatan terhadap Motorola kontemporer berkaitan dengan Xoom dan terhadap konsumen Jerman elektronik reseller JAY-tech di sama pengadilan Jerman, baik untuk pelanggaran desain klaim mencari perintah awal.

\section{CONCLUSION}

Terdapat beberapa faktor yang mempengaruhi pengguna smartphone tetap menggunakan merk Samsung meskipun telah terjadi pertikaian dengan Apple mengenai hak paten. Faktor yang diambil lebih pada 'kualitas layanan' pemilik merk terhadap pengguna smartphone, yang dapat mempengaruhi life style dan lingkungan sekitar. Faktorfaktor tersebut antara lain:

Efisiensi

Kepercayaan

Kehandalan

Dukungan Masyarakat Pelanggaran Paten
D. DISCUSSION

Pengadilan AS

Pada 24 Agustus 2012 juri kembali memvonis sebagian menguntungkan Apple. Ditemukan bahwa Samsung telah sengaja melanggar hak paten desain dan utilitas Apple dan juga diencerkan gaun perdagangan Apple terkait iPhone. Juri memberikan Apple \$ 1.049 miliyar kerusakan dan Samsung nol kerusakan dalam gugatan baliknya. Juri menemukan Samsung melanggar hak paten Apple pada iPhone "Bounce-Back Effect" (No.7 US Patent, 469.381), "On-screen Navigasi (No.7 US Patent, 844.915), dan "Tekan Untuk Zoom" (No.7 US Patent, 864.163), dan paten desain yang mencakup fitur iPhone seperti "tombol home, sudut dibulatkan dan tepi meruncing" (US D593087) dan "Ikon On-Screen" (US D604305). Desain paten 504.889 (menggambarkan desain hias iPad) adalah salah satu dari beberapa paten juri menyimpulkan Samsung tidak dilanggar. Jumlah ini secara fungsional dikurangi dengan ikatan diposting oleh Apple untuk perintah yang diberikan selama persidangan. Pengacara Apple mengajukan permohonan untuk menghentikan semua penjualan produk Samsung dikutip dalam pelanggaran paten AS, gerakan ditolak oleh Hakim Koh pada 17 Desember. 


\section{E. REFERENCE}

[1] O. M. Febriani and A. S. Putra, "Sistem Informasi Monitoring Inventori Barang Pada Balai Riset Standardisasi Industri Bandar Lampung," J. Inform. vol. 13, no. 1, pp. 90-98, 2014.

[2] A. S. Putra, "Paperplain: Execution Fundamental Create Application With Borland Delphi 7.0 University Of Mitra Indonesia," 2018.

[3] A. S. Putra, "2018 Artikel Struktur Data, Audit Dan Jaringan Komputer," 2018.

[4] A. S. Putra, "ALIAS MANAGER USED IN DATABASE DESKTOP STUDI CASE DB DEMOS."

A. S. Putra, "COMPREHENSIVE SET OF PROFESSIONAL FOR DISTRIBUTE COMPUTING."

[6] A. S. Putra, "DATA ORIENTED RECOGNITION IN BORLAND DELPHI 7.0."

[7] A. S. Putra, "EMBARCADERO DELPHI XE 2 IN GPUPOWERED FIREMONKEY APPLICATION."

[8] A. S. Putra, "HAK ATAS KEKAYAAN INTELEKTUAL DALAM DUNIA TEKNOLOGY BERBASIS REVOLUSI INDUSTRI 4.0."

[9] A. S. Putra, "IMPLEMENTASI PERATURAN

PERUNDANGAN UU. NO 31 TAHUN 2000 TENTANG DESAIN INDUSTRI BERBASIS INFORMATION TECHNOLOGY."
[10] A. S. Putra, "IMPLEMENTATION OF PARADOX DBASE."

[11] A. A. S. Putra, "IMPLEMENTATION OF TRADE SECRET CASE STUDY SAMSUNG MOBILE PHONE."

[12] A. S. Putra, "IMPLEMENTATION

PATENT FOR APPLICATION WEB BASED CASE STUDI WWW. PUBLIKLAMPUNG. COM."

[13] A "IMPLEMENTATION SYSTEM FIRST TO INVENT IN DIGITALLY INDUSTRY."

[14] A. S. Putra, "MANUAL REPORT \& INTEGRATED DEVELOPMENT

ENVIRONMENT BORLAND DELPHI 7.0."

[15] A. S. Putra, "PATENT AS RELEVAN SUPPORT RESEARCH."

[16] A. S. Putra, "PATENT FOR RESEARCH STUDY CASE OF APPLE. Inc."

[17] A. S. Putra, "PATENT PROTECTION FOR APPLICATION INVENT."

[18] A. S. Putra, "QUICK REPORT IN PROGRAMMING." PROPERTY

[19] A. S. Putra, "REVIEW CIRCUIT LAYOUT COMPONENT

REQUIREMENT ON ASUS NOTEBOOK."

[20] A. S. Putra, "REVIEW TRADEMARK PATENT FOR INDUSTRIAL TECHNOLOGY BASED 4.0."

[21] A. S. Putra, "TOOLBAR 
COMPONENT PALLETTE IN OBJECT ORIENTED

PROGRAMMING."

[22] A. S. Putra, "WORKING DIRECTORY SET FOR PARADOX 7."

[23] A. S. Putra, "ZQUERY CONNECTION

IMPLEMENTED

PROGRAMMING

STUDI

CASE PT. BANK BCA Tbk."

[24] A. S. Putra, D. R. Aryanti, and I. Hartati, "Metode SAW (Simple Additive Weighting) sebagai Sistem Pendukung Keputusan Guru Berprestasi (Studi Kasus: SMK Global Surya)," in Prosiding Seminar Nasional Darmajaya, 2018, vol. 1, no. 1, pp. 85-97.

[25] A. S. Putra and O. M. Febriani, "Knowledge Management Online Application in PDAM Lampung Province," in Prosiding International conference on Information Technology and Business (ICITB), 2018, pp. 181-187.

[26] A. S. Putra, O. M. Febriani, and B. Bachry, "Implementasi Genetic Fuzzy System Untuk Mengidentifikasi Hasil Curian Kendaraan Bermotor Di Polda Lampung," SIMADA (Jurnal Sist. Inf. dan Manaj. Basis Data), vol. 1, no. 1, pp. 21-30, 2018.

[27] A. S. Putra, H. Sukri, and K. Zuhri, "Sistem Monitoring Realtime Jaringan Irigasi Desa (JIDES) Dengan Konsep Jaringan Sensor Nirkabel," IJEIS (Indonesian J. Electron. Instrum. Syst., vol. 8, no. 2, pp. 221-232.
[28] D. P. Sari, O. M. Febriani, and A. S. Putra, "Perancangan Sistem Informasi SDM Berprestasi pada SD Global Surya," in Prosiding Seminar Nasional Darmajaya, 2018, vol. 1, no. 1, pp. 289-294. 